\section{References}

1. Boissier J, Grech-Angelini S, Webster BL, Allienne JF, Huyse T, Mas-Coma S, et al. Outbreak of urogenital schistosomiasis in Corsica (France): an epidemiological case study. Lancet Infect Dis. 2016;16:971-9. http://dx.doi.org/10.1016/ S1473-3099(16)00175-4

2. Schlagenhauf P, Weld L, Goorhuis A, Gautret P, Weber R, von Sonnenburg F, et al.; EuroTravNet. Travel-associated infection presenting in Europe (2008-12): an analysis of EuroTravNet longitudinal, surveillance data, and evaluation of the effect of the pre-travel consultation. Lancet Infect Dis. 2015; 15:55-64. http://dx.doi.org/10.1016/S1473-3099(14)71000-X

3. Beltrame A, Buonfrate D, Gobbi F, Angheben A, Marchese V, Monteiro GB, et al. The hidden epidemic of schistosomiasis in recent African immigrants and asylum seekers to Italy. Eur J Epidemiol. 2017;32:733-5. http://dx.doi.org/10.1007/ s10654-017-0259-6

4. Meurs L, Mbow M, Vereecken K, Menten J, Mboup S, Polman K. Epidemiology of mixed Schistosoma mansoni and Schistosoma haematobium infections in northern Senegal. Int J Parasitol. 2012;42:305-11. http://dx.doi.org/10.1016/j.ijpara.2012.02.002

5. Huyse T, Van den Broeck F, Hellemans B, Volckaert FA, Polman K. Hybridisation between the two major African schistosome species of humans. Int J Parasitol. 2013;43:687-9. http://dx.doi.org/10.1016/j.ijpara.2013.04.001

6. Moné H, Holtfreter MC, Allienne JF, Mintsa-Nguéma R, Ibikounlé M, Boissier J, et al. Introgressive hybridizations of Schistosoma haematobium by Schistosoma bovis at the origin of the first case report of schistosomiasis in Corsica (France, Europe). Parasitol Res. 2015;114:4127-33. http://dx.doi.org/10.1007/ s00436-015-4643-4

7. Moné H, Holtfreter MC, Mouahid G, Richter J. Difficulties in schistosomiasis assessment, Corsica, France. Emerg Infect Dis. 2016;22:762-3. http://dx.doi.org/10.3201/eid2204.160110

8. Webster BL, Southgate VR. Compatibility of Schistosoma haematobium, S. intercalatum and their hybrids with Bulinus truncatus and B. forskalii. Parasitology. 2003;127:231-42. http://dx.doi.org/10.1017/S0031182003003597

9. Majoros G, Fehér Z, Deli T, Földvári G. Establishment of Biomphalaria tenagophila snails in Europe. Emerg Infect Dis. 2008;14:1812-4. http://dx.doi.org/10.3201/eid1411.080479

10. Lingscheid T, Kurth F, Clerinx J, Marocco S, Trevino B, Schunk M, et al.; TropNet Schistosomiasis Investigator Group. Schistosomiasis in European travelers and migrants: analysis of 14 years TropNet surveillance data. Am J Trop Med Hyg. 2017;97:567-74. http://dx.doi.org/10.4269/ajtmh.17-0034

11. Welter-Schultes F. European non-marine molluscs, a guide for species identification. Gottingen, Germany: Planet Poster Editions; 2012.

Address for correspondence: Jérôme Boissier, CNRS, UMR 5244, 52 Avenue Paul Alduy, Perpignan 66000, France; email: boissier@univ-perp.fr

\title{
West Nile Virus Infection in Travelers Returning to United Kingdom from South Africa
}

\author{
Vivak Parkash, Kate Woods, \\ Liana Kafetzopoulou, Jane Osborne, \\ Emma Aarons, Katharine Cartwright
}

Author affiliations: Royal Hallamshire Hospital, Sheffield, UK (V. Parkash, K. Cartwright); Public Health England, Porton Down, UK (K. Woods, L. Kafetzopoulou, J. Osborne, E. Aarons)

DOI: https://doi.org/10.3201/eid2502.172101

West Nile virus (WNV) is an arthropod-transmitted flavivirus that causes West Nile fever and may infrequently cause neuroinvasive disease in humans. We present 2 cases of confirmed WNV infection, 1 of severe encephalitis and 1 of mild febrile illness, in a couple returning to the United Kingdom from South Africa.

$\mathrm{W}$ est Nile virus (WNV) is a mosquitoborne flavivirus maintained in an enzootic cycle between culicine mosquitoes and birds. Approximately $80 \%$ of human infections are subclinical, although symptomatic cases can vary from influenza-like symptoms to neurotropic manifestations (1). West Nile neuroinvasive disease, which manifests as encephalitis, meningitis, or acute flaccid paralysis, occurs in $<1 \%$ of all cases (2).

To date, human disease caused by WNV has been attributed to WNV phylogenetic lineages 1 and 2 (3). Lineage 2 consists of viruses found in South Africa, Madagascar, and, more recently, in Europe and Russia (4). Lineage 2 was previously described as less pathogenic than lineage 1 , but it has subsequently been demonstrated that lineage 2 can also lead to neuroinvasive disease (5). We describe a couple from the United Kingdom with confirmed WNV infection who were admitted to a hospital in February 2017 on return from a holiday to South Africa, where they most likely acquired WNV in the Kruger National Park region.

A previously healthy 76-year-old woman was admitted with acute confusion to Doncaster Royal Infirmary, Doncaster, UK. She and her husband had returned that day following a 3-week holiday visiting family in South Africa (Appendix Figure, http://wwwnc.cdc.gov/EID/article/25/2/172101-App1.pdf). The patient and her husband had stayed in Johannesburg, except for a 5-day safari in Kruger National Park 5 days into their trip. They had both sustained several mosquito and tick bites. No malaria prophylaxis had been taken, and no pretravel advice had been sought.

The patient boarded an airplane independently in Johannesburg but her condition deteriorated in flight; on arrival, 
Table. Diagnostic investigations for the index case of West Nile virus infection in a woman from the United Kingdom who traveled to South Africa*

\begin{tabular}{|c|c|c|c|}
\hline Test & Result & Reference range & Day of testing $\dagger$ \\
\hline \multicolumn{4}{|l|}{ Blood tests } \\
\hline White cell count & $12.2 \times 10^{9} \mathrm{cells} / \mathrm{L}$ & $3.5-9.5 \times 10^{9} / \mathrm{L}$ & 1 \\
\hline C-reactive protein & $81 \mathrm{mg} / \mathrm{L}$ & $0-5 \mathrm{mg} / \mathrm{L}$ & 1 \\
\hline Creatine kinase & $593 \mathrm{U} / \mathrm{L}$ & $25-200 \mathrm{U} / \mathrm{L}$ & 1 \\
\hline Glucose & $7 \mathrm{mmol} / \mathrm{L}$ & $3-6 \mathrm{mmol} / \mathrm{L}$ & 1 \\
\hline \multicolumn{4}{|l|}{ Liver function tests } \\
\hline Alkaline phosphatase & $60 \mathrm{IU} / \mathrm{L}$ & $30-130 \mathrm{IU} / \mathrm{L}$ & 3 \\
\hline Aspartate aminotransferase & $33 \mathrm{IU} / \mathrm{L}$ & 0-32 IU/L & 3 \\
\hline Gamma glutamyl transferase & $78 \mathrm{IU} / \mathrm{L}$ & $0-40 \mathrm{IU} / \mathrm{L}$ & 3 \\
\hline Gamma glutamyl transferase & $155 \mathrm{IU} / \mathrm{L}$ & $0-40 \mathrm{IU} / \mathrm{L}$ & 11 \\
\hline Alanine aminotransferase & $35 \mathrm{IU} / \mathrm{L}$ & $0-33 \mathrm{IU} / \mathrm{L}$ & 3 \\
\hline Alanine aminotransferase & 37 IU/L & 0-33 IU/L & 6 \\
\hline \multicolumn{4}{|l|}{ Malaria testing } \\
\hline Rapid antigen detection $\ddagger$ & Negative & & 1 \\
\hline Thick/thin blood films & Negative & & $1,2,3$ \\
\hline \multicolumn{4}{|l|}{ Lumbar puncture } \\
\hline Visual appearances & Clear, colorless CSF & & 2 \\
\hline Opening pressure & $22 \mathrm{~cm} \mathrm{H}_{2} \mathrm{O}$ & $5-18 \mathrm{~cm} \mathrm{H}_{2} \mathrm{O}$ & 2 \\
\hline Leukocyte count & $102 \times 10^{6}$ cells $/ \mathrm{L}$ & $\leq 5 \times 10^{6} \mathrm{cells} / \mathrm{L}$ & 2 \\
\hline Leukocyte differential & $\begin{array}{l}80 \% \text { polymorphonuclear cells; } \\
20 \% \text { lymphocytes }\end{array}$ & & \\
\hline CSF protein & $1.24 \mathrm{~g} / \mathrm{L}$ & $0.15-0.45 \mathrm{~g} / \mathrm{L}$ & 2 \\
\hline CSF glucose & $3 \mathrm{mmol} / \mathrm{L}$ & $3.3-4.4 \mathrm{mmol} / \mathrm{L}$ & 2 \\
\hline \multicolumn{4}{|l|}{ CSF molecular assays } \\
\hline Herpes simplex virus DNA & Not detected & & 2 \\
\hline Varicella zoster virus DNA & Not detected & & 2 \\
\hline Enterovirus RNA & Not detected & & 2 \\
\hline Meningococcus DNA & Not detected & & 2 \\
\hline Pneumococcus DNA & Not detected & & 2 \\
\hline Listeria DNA & Not detected & & 2 \\
\hline \multicolumn{4}{|l|}{ Serology and blood cultures } \\
\hline Blood cultures & No growth after $5 \mathrm{~d}$ & & $1,3,5$ \\
\hline HIV screen & Negative & & 3 \\
\hline Syphilis screen & Negative & & 3 \\
\hline \multicolumn{4}{|l|}{ Imaging and EEG } \\
\hline Chest radiograph & Unremarkable & & 1 \\
\hline Contrast MRI of the brain & $\begin{array}{l}\text { No leptomeningeal } \\
\text { enhancement; established } \\
\text { right cerebellar infarct }\end{array}$ & & 5 \\
\hline EEG & $\begin{array}{l}\text { Rhythmic irregular delta slow- } \\
\text { wave activity (suggestive of } \\
\text { encephalopathy) }\end{array}$ & & 11 \\
\hline $\begin{array}{l}\text { SF, cerebrospinal fluid; EEG, elec } \\
\text { After hospital admission. } \\
\text { Plasmodium lactate dehydrogenas }\end{array}$ & $\begin{array}{l}\text {; MRI, magnetic resonance imaging } \\
\text { MAL-IT, Bio-Rad, http://www.bio-ra }\end{array}$ & & \\
\hline
\end{tabular}

she was transferred directly to the hospital. She was febrile, hypotensive, and agitated, with a Glasgow Coma Score fluctuating between 7 and 14, and had intermittent vacant episodes (Table). She was empirically treated for meningoencephalitis with intravenous cefotaxime, amoxicillin, and aciclovir. Because of her travel history, intravenous artesunate was added for possible malaria and doxycycline for possible rickettsial infections. On the second day of admission, the patient was transferred to the Department of Infection and Tropical Medicine (Sheffield, UK).

After discussion with the Imported Fever Service, we sent blood, cerebrospinal fluid (CSF), and urine samples to the Public Health England Rare and Imported Pathogens Laboratory (RIPL) for testing (Appendix Figure). By ELISA, serum was strongly positive for WNV IgM but negative for IgG. WNV RNA was detected in urine by reverse transcription PCR (RT-PCR), confirming the diagnosis. CSF test results were abnormal (Table) but negative for both WNV RNA and IgM. Follow-up serum specimens taken 2 weeks later demonstrated seroconversion of WNV IgG (ELISA). Subsequent whole-genome sequencing of virus detected in the urine sample demonstrated that it belonged to WNV lineage 2.

Empirical antimicrobial drug treatment was stopped, and the patient's Glasgow Coma Score improved to 14, with residual mild cognitive impairment, ongoing balance disorder, and improving myalgia. Inflammatory markers and all other blood parameters normalized before discharge 5 weeks later. At follow-up 12 weeks after presentation, the patient's cognition had 
improved, but she still required use of a cane for persistent balance disturbance.

One day after the index patient's admission, her 72-year-old husband was admitted with an influenza-like illness. He had stage 3 chronic kidney disease but no other concurrent conditions. Urine and serum samples were obtained, and test results confirmed that he, too, had had a recent WNV infection. WNV IgM and IgG were positive in serum 5 days after symptom onset; WNV RT-PCR on urine was negative. He had no neurologic component to his illness and made a rapid clinical recovery.

WNV was initially isolated from a febrile patient in Uganda in 1937 (6). The virus was not correlated with severe human disease until the 1990s, when outbreaks in Europe were associated with higher rates of West Nile neuroinvasive disease (7). WNV is sporadically reported from South Africa (8). Imported cases to the United Kingdom are rare, and autochthonous infections have yet to be reported. One other RT-PCR-confirmed case of acute WNV infection has been reported in a traveler returning to the United Kingdom since 2012; 7 other clinically suspected cases have shown compatible WNV serologic test results (Public Health England, unpub. data).

Clinicians should bear in mind the value of urine sampling to detect WNV RNA by RT-PCR in addition to serologic testing. WNV is excreted in high concentrations in urine and may be detected for several weeks postinfection, whereas detectable virus in serum and CSF is transient and generally not present by the time of symptom onset (9). Detection of WNV IgM in CSF is used to confirm neuroinvasive disease. WNV IgG appears shortly after IgM but remains positive in the long term and is therefore not a useful marker of recent infection unless seroconversion is demonstrated.

Clinicians should be alert to the possibility of arthropodborne infections in travelers returning from South Africa. These include WNV, African tick-bite fever, chikungunya, and Plasmodium falciparum malaria. In addition, an outbreak of arboviral infections, particularly Sindbis virus, had been reported in the Johannesburg area coinciding with the travel dates of the patients we report (10).

\section{Acknowledgments}

We acknowledge the Emerging Zoonotic Infections team at Colindale and Lucille Blumberg and the travel health team at the National Institute for Communicable Diseases, South Africa, for their liaison on the public health aspects of these cases. We also extend our gratitude to Gillian Slack for her work on the molecular diagnosis of the index case and to Joyeeta Palit, who was involved in the clinical care of both patients.

\section{About the Author}

Dr. Parkash is a general internal medicine and infectious diseases clinician at Sheffield Teaching Hospitals NHS Foundation Trust, United Kingdom. His research interests include leishmaniasis and imported tropical infectious diseases.

\section{References}

1. Suthar MS, Diamond MS, Gale M Jr. West Nile virus infection and immunity. Nat Rev Microbiol. 2013;11:115-28. http://dx.doi.org/ 10.1038/nrmicro2950

2. Hart J Jr, Tillman G, Kraut MA, Chiang HS, Strain JF, Li Y, et al.; NIAID Collaborative Antiviral Study Group West Nile Virus 210 Protocol Team. West Nile virus neuroinvasive disease: neurological manifestations and prospective longitudinal outcomes. BMC Infect Dis. 2014;14:248. http://dx.doi.org/10.1186/ 1471-2334-14-248

3. David S, Abraham AM. Epidemiological and clinical aspects on West Nile virus, a globally emerging pathogen. Infect Dis (Lond). 2016;48:571-86. http://dx.doi.org/10.3109/23744235.201 6.1164890

4. May FJ, Davis CT, Tesh RB, Barrett ADT. Phylogeography of West Nile virus: from the cradle of evolution in Africa to Eurasia, Australia, and the Americas. J Virol. 2011;85:2964-74. http://dx.doi.org/10.1128/JVI.01963-10

5. Botha EM, Markotter W, Wolfaardt M, Paweska JT, Swanepoel R, Palacios G, et al. Genetic determinants of virulence in pathogenic lineage 2 West Nile virus strains. Emerg Infect Dis. 2008; 14:222-30. http://dx.doi.org/10.3201/eid1402.070457

6. Smithburn KC, Hughes TP, Burke AW, Paul JH. A neurotropic virus isolated from the blood of a native of Uganda. Am J Trop Med. 1940;20:471-2.

7. Eberhard ML, da Silva AJ, Lilley BG, Pieniazek NJ. Morphologic and molecular characterization of new Cyclospora species from Ethiopian monkeys: C. cercopitheci sp.n., C. colobi sp.n., and C. papionis sp.n. Emerg Infect Dis. 1999;5:651-8. http://dx.doi.org/10.3201/eid0505.990506

8. Hernández-Triana LM, Jeffries CL, Mansfield KL, Carnell G, Fooks AR, Johnson N. Emergence of West Nile virus lineage 2 in Europe: a review on the introduction and spread of a mosquito-borne disease. Front Public Health. 2014;2:271. http://dx.doi.org/10.3389/fpubh.2014.00271

9. Barzon L, Pacenti M, Franchin E, Squarzon L, Sinigaglia A, Ulbert $\mathrm{S}$, et al. Isolation of West Nile virus from urine samples of patients with acute infection. J Clin Microbiol. 2014;52:3411-3. http://dx.doi.org/10.1128/JCM.01328-14

10. ProMED-mail. Arbovirus clusters - South Africa: West Nile, Sindbis, alert. 2017 Feb 24 [cited 2017 May 15]. http://promedmail.org, archive no. 20170224.4861086.

Address for correspondence: Vivak Parkash, Royal Hallamshire Hospital, Department of Infection and Tropical Medicine, Glossop

Road, Sheffield S10 2JF, UK; email: vivak.parkash@sth.nhs.uk 